\title{
A Review of Three Significant Geohazards in the Canadian Cordillera: the Case of River Floods, Debris Flows/Floods, and Debris/Rock Avalanches
}

\author{
Olav Slaymaker \\ Department of Geography, The University of British Columbia, Vancouver, Canada
}

\begin{abstract}
Research into sudden-onset geohazards, such as river floods, debris flows/floods and debris/rock avalanches is prominent in literature on the Canadian Cordillera. The unresolved question is the relative importance of river floods, debris flows/floods and debris/rock avalanches over shorter and longer time scales and at smaller and larger spatial scales. River flooding is the costliest geohazard at regional scale and over century time scales but debris/rock avalanches are the deadliest at individual slope scale and over seasonal time scale. In terms of work done on the landscape, debris flows/floods are the most pervasive geohazard and have a huge influence on the long-term moulding of the landscape but figure less prominently in terms of fatalities and cost. Intensified land use, such as forestry, mining, agriculture and urbanization, is the primary reason for the increase in the cost of geohazards to society over the past three decades but climate change adds further uncertainties to the assessment of future geohazards.
\end{abstract}

Keywords: Canadian Cordillera, geohazards, forestry, mining, agriculture, urbanization, river floods, debris flows/floods, debris/rock avalanches

\section{Introduction: Definition of Geohazards}

Geohazards have been defined as long-term or short-term geological and environmental processes that lead to damage or risk. Geohazards may operate over small areas but they can also affect local and regional economies (Koch 1995). The reflexive relation between society and the environment is implicit in this definition such that, in the absence of people, there are, strictly speaking, no geohazards (White 1974). Three suites of sudden-onset geohazards that are known to be important in the Cordillera have been selected for review, namely river floods, debris flows/floods and debris/rock avalanches (as defined in Hungr et al 2001). Other sudden onset geohazards, such as earthquakes, tsunamis, volcanoes, meteorites, snow avalanches and geomagnetic hazards, are difficult to evaluate because of the shortage of historical data (Brooks et al 2001). The economic impact of a hypothetical magnitude 6.5 crustal earthquake with a focus $10 \mathrm{~km}$ beneath Vancouver, for example, could cause a total economic loss of 14 - 32 billion dollars (Etkin et al 2004).

\section{Causes of Instability in the Canadian Cordillera}

There is a high incidence of slope and channel instability in the Canadian Cordillera, the mountainous region of western Canada that includes most of Yukon and British Columbia and parts of Alberta and Northwest Territories. The total area of the Cordillera is 1.6 million $\mathrm{km}^{2}$. The Cordillera is tectonically active, volcanism is widespread, ground subsidence and snow avalanches are common; permafrost is widespread in discontinuous, sporadic and isolated form and, in the present context of

* Corresponding Author: Olav Slaymaker, Email: olav.slaymaker@ubc.ca, Tel: 
warming temperatures, permafrost thawing is encouraging enhanced mass movement, glacier dam bursts and jokulhlaups (Clague and Evans 1998).

The main contextual reason for the high incidence of instability in the Canadian Cordillera is that it is a landscape that is still recovering from the Cordilleran Ice Sheet cover of the Last Glacial Maximum (LGM) (c. $18 \mathrm{ka} \mathrm{BP}$ ) and the present (Fig. 1; Church and Ryder 1972, Church and Slaymaker 1989).

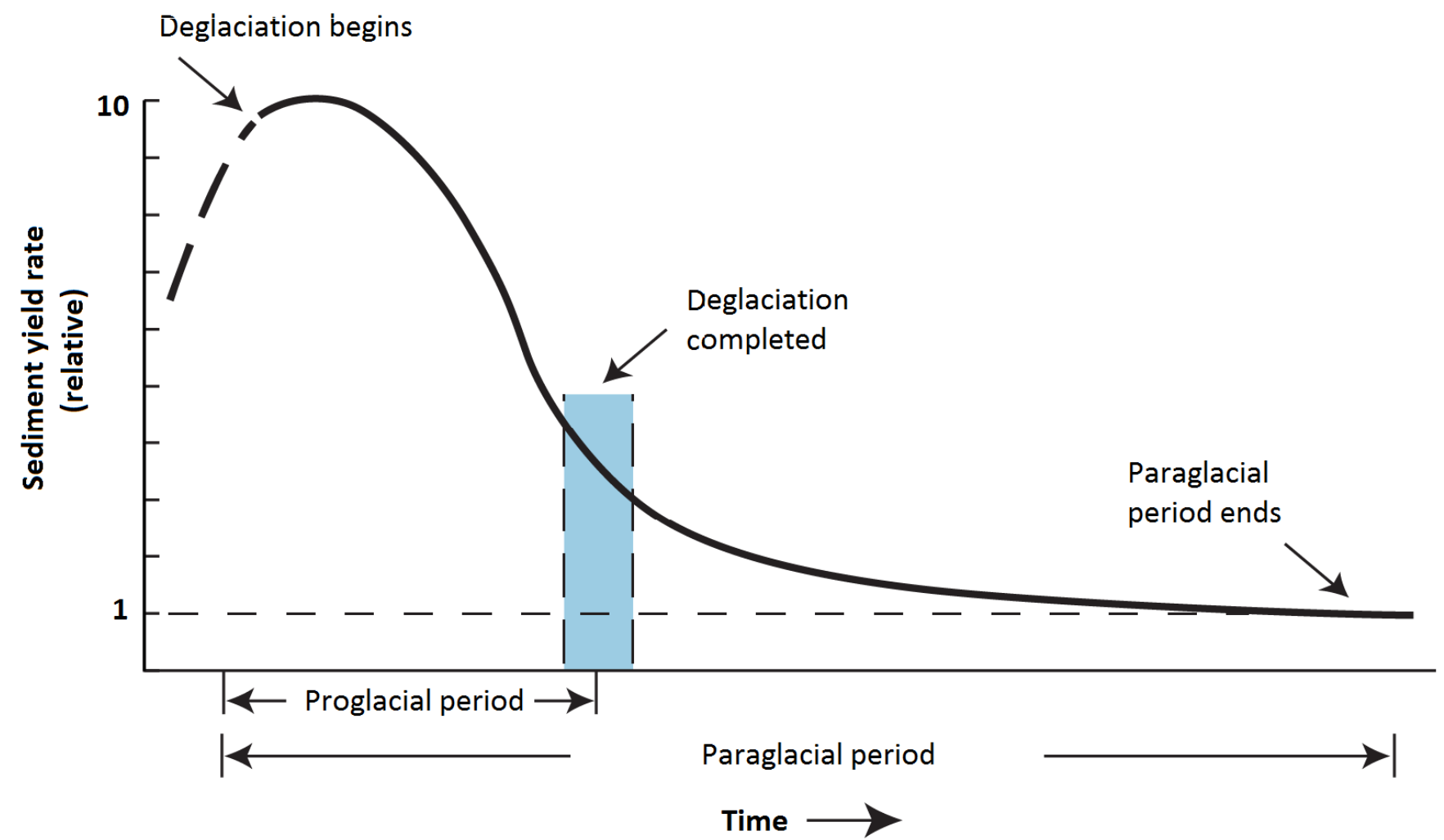

There are three phases of the landscape recovery process since the LGM: the Holocene transition from glacial to fluvial and mass wasting process dominance; the Anthropocene transition concerns the intensification and diversification of land use associated with the increasing population of the past century; and the hydroclimate change transition over the past 25 years or so, the implications of which remain incomplete. Each transition has altered and continues to alter the hazardousness of the region.

Figure 1. The paraglacial period according to Church and Ryder (1972)

\subsection{Landscape recovery since the LGM}

\subsubsection{The Holocene transition}

The Holocene transition is known as the paraglacial period (Fig. 1) at the beginning of which the landscape was thinly populated by First Nations immigrants largely from Asia. Evidence of geohazards from this period is difficult to assemble but at least three occupied sites, in the Fraser Valley (Orwin et al 2004), in the FraserThompson drainage (Stryd and Rousseau 1996) and in northwestern BC (Sutherland-Brown 1969), have been overwhelmed by a rock avalanche, a 
through the glaciated Ruby Range to the unglaciated areas north of the Ruby Range, Yukon, illustrates the difference between geohazards in glacierized areas (largely cryospheric), in paraglacial areas (large mass movements and river floods) and in unglaciated areas (river floods and thawing permafrost) (Johnson 1984). Johnson noted that large mass movement forms were characteristic of the high mountain paraglacial environment. Jordan and Slaymaker (1991) described a previously unaccounted source of contemporary sediment production, namely the weathering products of the Quaternary volcanics and flood sediments associated with extension of land use on river floodplains. Friele et al (2008) and Friele and Clague (2009) have identified the Garibaldi Quaternary Volcanic Centre as an end member in the spectrum of landscape response to Pleistocene deglaciation. Postglacial sediment yield in major river basins reflects the successive effects of paraglaciation, volcanism, human impact, and glacier recession, all of which mark stages in the Holocene transition (Church and Slaymaker 1989).

\subsubsection{The Anthropocene transition}

The Canadian Cordillera (BC, Alberta, Yukon and NWT) is lightly populated with of the order of 200,000 residents within the mountain region itself, of whom $75 \%$ are First Nations or aboriginal peoples. Sixteen of the twenty one land claim agreements that were achieved in Canada from 1975-2009 occurred in Yukon (9), NWT (5) and British Columbia (2). Land claim negotiations are insisting not only on property rights, but political, social and cultural rights. Aboriginal corporations and the Canadian Federal government now make joint decisions on development, wildlife management and environmental protection. No stable economic development can occur in the Canadian Cordillera without mutually satisfactory land claim agreements. Aboriginal resistance has been central to the economic and social evolution of Canada's Cordillera. The population density of $<0.2 \mathrm{~km}^{-2}$ implies that geohazards may be relatively scarce. But this would be a mistaken assumption because distributed land use, such as forest management, and site intensive land use, such as mining, require a road network that is vulnerable to disruption by geohazards. Recent experience with oil and gas pipeline development is also fraught. Increasingly urban development has intensified processes of mass movement and river flooding (Evans 1982, Slaymaker and Embleton-Hamann 2009).

\subsubsection{The climate change transition}

A systematic survey of the alpine landscapes of Canada (Ryder 1998) demonstrated the probable effects of climate change over the next 50 years. Moore et al (2009) have considered the effects of climate change on hydrology, geohazards and water quality in the Cordillera. A number of studies have addressed the influence of climate change on hydrology and river floods (McBean et al 1991, Woo 1996), river ice break up (Prowse and Beltaos 2002, Beltaos and Burrell 2003), permafrost thawing (Haeberli and Burn 2002), and glacier mass loss and thinning (Geertsema and Chiarle 2013, Clarke et al 2015). Natural dam failures associated with glacier retreat are widespread in the Western Cordillera (Evans and Clague 1997), whereas mass movement induced by permafrost thawing is more common in the Eastern Cordillera. The precise effects of the climate change transition on geohazards are difficult to pin down because of the interaction between land use intensification and extreme hydrometeorologic and cryospheric events.

\subsection{Policy and governance}

Land use practices and policy governing land development are often the most important drivers of geohazards (Slaymaker 1999, 2001). There is as yet no unified policy to promote geohazard management in the Canadian Cordillera. The problem is not in the quantity and quality of geohazard assessments but the problem lies in the isolation of the work from broader risk perspectives and in the lack of clarity in division of responsibilities between various levels of government. Social and political priorities often trump geoscience priorities (Slaymaker 1999). The 1990s was the decade in which it was first documented that the fraction of land deliberately changed by humankind was approaching 50\% 
world-wide. The use of land to provide goods and services is the most substantial human alteration of the Earth. It seems clear that land use change on this scale requires an integration of the social, economic and cultural causes of land changes with evaluation of its biophysical nature and consequences (Hewitt 1989, 2006, Vitousek et al 1997). Geohazards are best considered within a broader context of management for sustainable development, which often leads to a focus on decision making under conditions of uncertainty (Slaymaker 1999).

\section{Geohazards of Interest}

\subsection{Classification of mass movements of the flow type}

The key differentiator between debris flows/floods and debris/rock avalanches is the presence of an established channel or regular confined path in the former case; in the case of avalanches, the lack of channeling, a lesser degree of sorting and a coarse front are diagnostic. It should also be acknowledged that landslides of a flow type are important as geohazards (Hungr et al 2001, p.221). The rock avalanche geohazard is distinctive in that avalanches are localized (point) events. When debris flows and floods are considered the attributes of location, time and magnitude have to be considered (Evans 1997). The net impact of a geohazard on the landscape and on society is commonly calculated in terms of cost and/or fatalities; from a geomorphological perspective, the total energy expended or the amount of sediment transported are equally important parameters. Then there is the problem of spatial scale: how can one compare the importance of a violent geohazard at an individual slope scale with that of a less violent geohazard that is distributed over a large drainage basin? Total energy expended or work done on the landscape is a measure adopted by some geomorphologists but, as indicated in section 1, if no economic damage is caused and no fatalities occur, we are not, strictly speaking, dealing with a hazard. Finally, there is the problem of time scale: whether the hazard should be evaluated over a seasonal, decadal or millennial time scale.
Geohazards are ranked differently depending on the time scale of interest.

\subsection{River floods}

River floods are defined as "bankfull exceedances", a definition which is unambiguous in theory but turns out to be more complex in practice (Leopold and Maddock 1953). Floods are an integral part of the flow regime of alluvial rivers with geomorphic effects ranging from negligible to large scale erosion and deposition and channel avulsions that alter the character of the whole valley bottom. Flood disasters in the Cordillera are concentrated in May/June and have become progressively more damaging over the past century (Fig. 2). Intensified land use in flood-prone areas is generally responsible for the bulk of the cost (Sandink et al 2010). The river flood hazard is the costliest of the three geohazards considered here (McBean 2012). Although historically river floods have been the second most costly geohazard in Canada, they are indeed the costliest of sudden onset geohazards (Brooks et al 2001). According to Etkin et al (2004), drought is the costliest geohazard in Canada but this is a slow onset geohazard that we will not be able to consider in this discussion

Flood producing mechanisms include: (a). hydrometeorological: snowmelt runoff, storm rainfall, rain-on-snow, ice jam; and (b). related to natural dams: landslide dams, glacier dams, moraine dams, icings (Brooks et al 2001). Hydrometeorological floods (except for ice jam floods) can be forecast with the aid of models; natural dam floods are more difficult and produce peak discharges that are an order of magnitude greater than the maximum expected normal hydrological flood (Brooks et al 2001). According to Brooks et al (2001), prior to 1949 there were only 5 "major floods" in the Cordillera, and from 1949 to 1997 there were 22; there were 5 landslide dam failures before 1949 and 15 thereafter; and there were of the order of 10 glacier dam failures before 1949 and more than 63 from 1949 to 1997. Of course the level of monitoring was poor in the earlier period and settlements and transport corridors have become more intensively used; nevertheless, the flood 

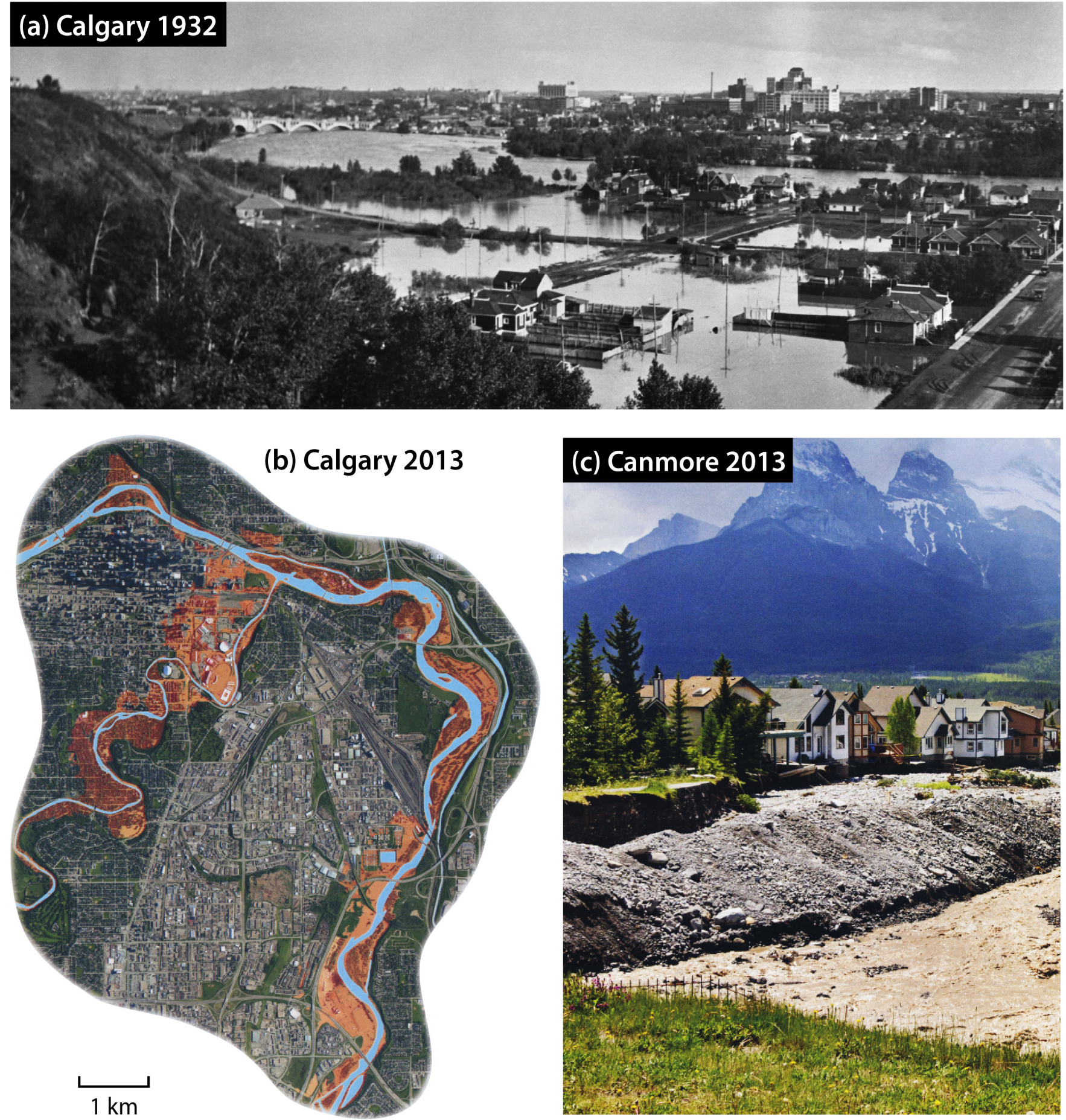

Figure 2a. River flooding on the north bank of the Bow River in Calgary, summer flood of June 5, 1932: Sunnyside. Source: Glenbow Archives, NA 1044-3; b. Highest flood level achieved in the 2013 Calgary flood around the junction of Elbow and Bow rivers; and c. Canmore river flood, June 22, 2013. Source: Chris Brackley, Canadian Geographic

hazard appears to have intensified. Changes in frequency of extreme weather events in western North America have been documented by Zhang et al (2001) and Shephard et al (2014).

River morphology and channel change depend to a great extent on mean discharge, magnitude and frequency of large floods, sediment supply and valley gradient. Whereas alluvial channels may respond to large flows by widening and deepening, semi-alluvial channels, such as those that one finds in the Cordillera may not adjust so quickly and so cause more extensive 
overbank flooding; however, sufficiently large changes in flow may trigger dramatic adjustments at a threshold point where the bed material becomes erodible (Ashmore and Church 2001). The big questions on this geohazard are: (a). whether the Anthropocene and climate transitions have altered the frequency of extreme river flood events, and (b). if statistical stationarity can no longer be assumed, how can we assess the risk of river flood-prone lands being inundated in the near future (Slaymaker and Embleton-Hamann 2009).

\subsection{Debris flows/floods}

Debris flows, debris floods and sediment-laden streamflow are a continuum based on water content and, strictly speaking, only the first of these phenomena is a landslide. A debris flow is a very rapid to extremely rapid flow of saturated non-plastic debris in a steep channel. Peak discharges of debris flows are up to 40 times greater than those of extreme floods (Hungr 2001). Materials involved in debris flows range from clays to boulders several meters in diameter.
In forested areas as much as $80 \%$ of the volume may be organic material (Slaymaker 1988). Debris flows are frequently generated by the channelization of a debris avalanche triggered in the upper slopes of a watershed, as illustrated in Fig. 3 (Van Dine 1985).

A debris flood by contrast with a debris flow is a very rapid, surging flow of water, heavily charged with debris in a steep channel. Because of the ability of a debris flood to transport large quantities of sediment, they form hyperconcentrated flows. The sediment surges in a debris flood are propelled by the tractive forces of water overlying the debris. In the Cordillera coarse debris flows typically occur in basins smaller than $5 \mathrm{~km}^{2}$ whereas debris floods occur in river basins up to $50 \mathrm{~km}^{2}$ and mean slope angles of less than $10^{\circ}$ (Jakob et al 2013, Lyle 2013).

Jordan and Slaymaker (1991) showed that debris flows/floods were the most important contributors to the sediment budget of the Lillooet River basin in British Columbia. A calculation of the landslide magnitude-frequency

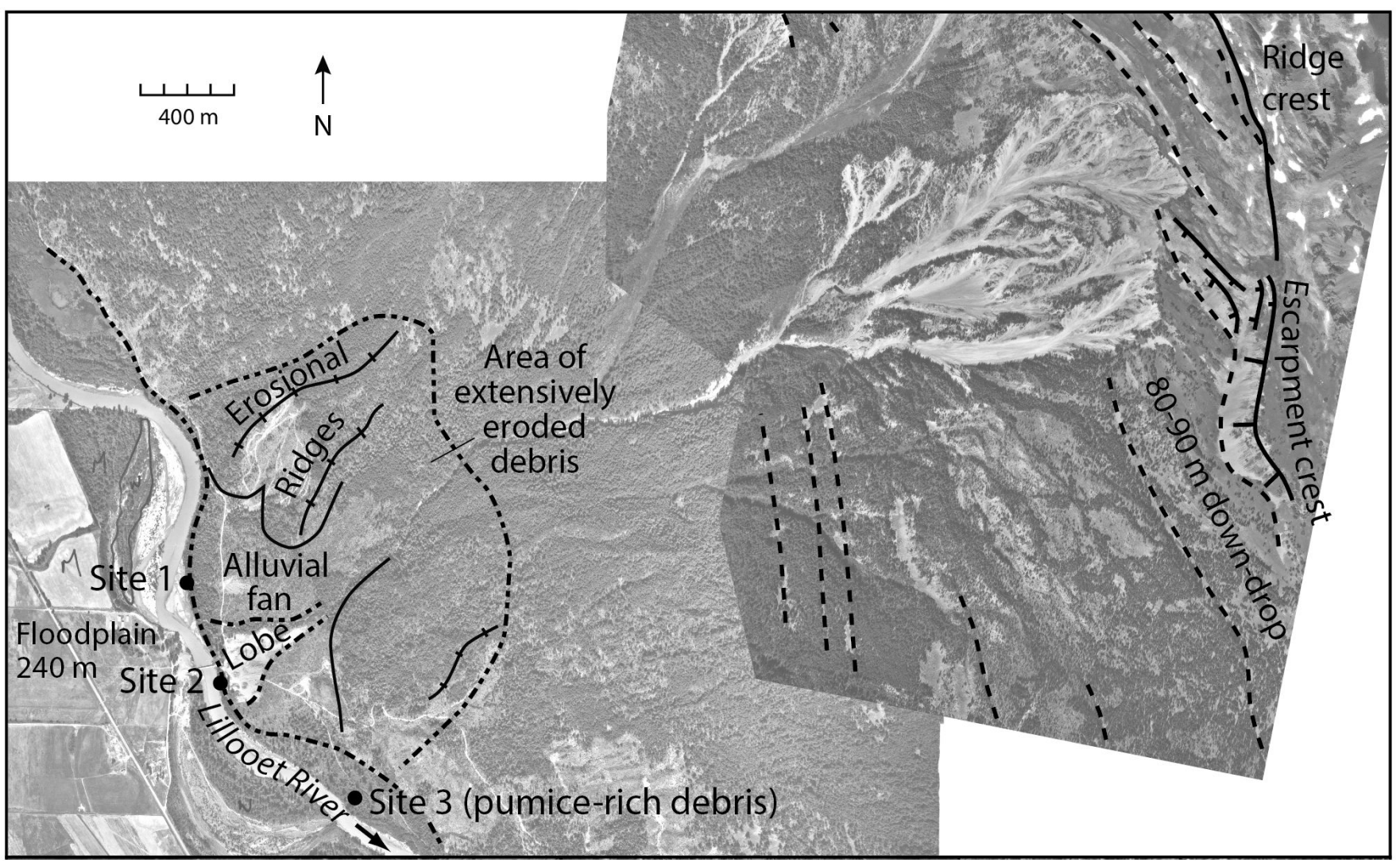

Figure 3. Sudden-onset geohazards such as debris flow/flood pathways, illustrated from Mt. Barbour, Lillooet River basin (photo composite assembled by P.A. Friele) 
relation (Brardinoni and Church 2004) demonstrated that intermediate size debris flows are responsible for more sediment movement to the outlet of the Capilano River basin in BC than the larger debris avalanches or the smaller debris flows. The recovery time of five river basins in coastal $\mathrm{BC}$ after forest harvesting is over 20 years but continuous disturbance of a basin may extend the recovery time considerably (Brardinoni et al 2002). In the Rocky Mountain Front and Main ranges, a total of 103 fans were studied to assess the occurrence and past frequency of debris flows by Jackson (1987). He was able to distinguish between those components of the fan that were contributed by debris flows and those that resulted from debris flood. Slope failures in glacilacustrine and glacimarine sediments, in permafrost terrain, in excavated slopes and under water are usually characterized as earth flows rather than debris flows due to their finer grained sediments (Dyke and Brooks 2000).

\subsection{Debris/rock avalanches}

Rock avalanches typically involve volumes greater than $10^{6} \mathrm{~m}^{3}$ and travel up to $10 \mathrm{~km}$ from their source. Depending on the degree of saturation, they commonly transform into debris flows. Over 30 high velocity rock avalanches are known to have occurred in the Cordillera since 1855 (Evans 2001, plus more recent $21^{\text {st }}$ century events). A number of paraglacial processes are activated as the pressure release from debuttressed slopes may generate sackung (or slope sag), catastrophic rock avalanches and ultimately debris flows and alluvial fans. Geertsema et al (2006) provided a comprehensive overview of large catastrophic landslides in the northern Cordillera.

Frequent collapse of Holocene lavas leads to rock falls on to glaciers, which convert down slope to rock avalanches (stürzström) and massive debris flows and braided streams. On August 6, 2010 the southwest flank of Mt. Meager collapsed into Capricorn Creek yielding $4.8 \times 10^{7} \mathrm{~m}^{3}$ of debris, about the same size as the Hope Slide of 1965 (Guthrie et al 2012). The flow ran $270 \mathrm{~m}$ up the opposing wall and split into two lobes, one of which ran $3 \mathrm{~km}$ up Meager Creek and the other descended Meager Creek and spread out into the Lillooet Valley (Fig. 4). The Mt. Meager Volcanic Complex dominates the supply of sediment to Lillooet River (Friele and Clague 2004). A landslide frequency-magnitude model for Mt. Meager based on large mass movement events (greater than $10^{6} \mathrm{~m}^{3}$ ). The calculated mean denudation rate is $3 \mathrm{~mm} \mathrm{yr}^{-1}$ or 3,000 Bubnovs, which is at least 50 times higher than the average for hyper maritime areas of $\mathrm{BC}$ (Friele et al 2008). Areas of the Canadian Cordillera that have been the sites of Quaternary volcanism are the extreme end member of "nonglacial processes conditioned by glaciation" and they are the loci of the most frequent large Holocene landslides (Friele and Clague 2009).

Debris avalanches are rapid flows of saturated materials in steepland terrain; they occur on open slopes and are not channelized. In the Canadian Cordillera they are common in forested steeplands and range from 20,000 to $60,000 \mathrm{~m}^{3}$.

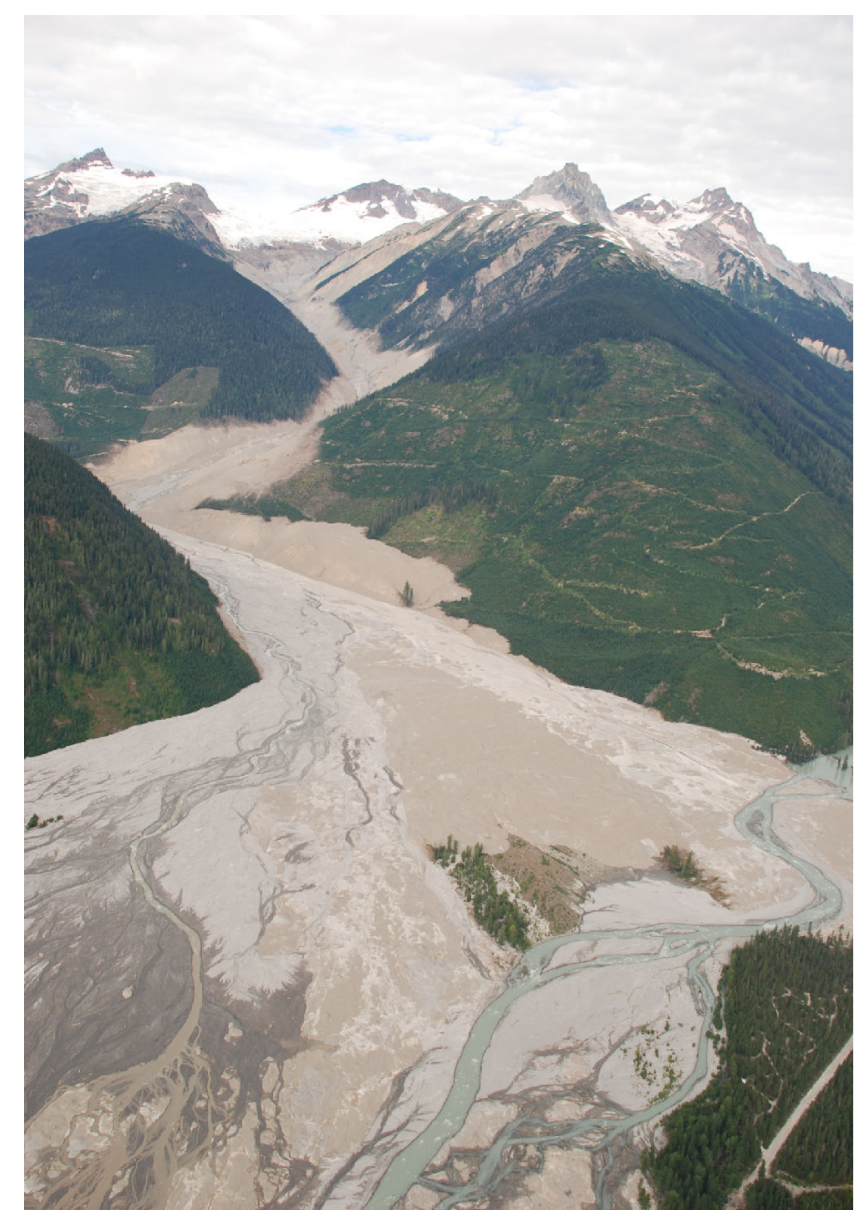


Figure 4. The 2010 Capricorn Creek rock avalanche/debris flow in the Mount Meager Volcanic Complex (oblique photo taken on August 29, 2010, by J.J. Clague)

Evans and Brooks (1991) identified three "debris avalanches" from 4800, 1100 and $500 \mathrm{BP}$ on the flanks of Mt. Cayley, a Quaternary volcano in the Garibaldi Volcanic Belt. The oldest of these was estimated at 2-3 x $10^{8} \mathrm{~m}^{3}$ and would likely be called a rock avalanche in the Hungr et al (2001) classification. The particular interest in these debris avalanches is that they threaten to dam the Squamish River. Lakes dammed by landslides, moraines and glaciers pose significant hazards to people and property in western Canada (Clague and Evans 1994).

\subsection{The role of land use and land management}

As explained in section 2.1.2, land use is a powerful driver of geohazards. As population densities increase and land utilization becomes more intensive, land use vies with hydroclimate as a primary driver (Lambin and Geist 2006, Slaymaker and Embleton-Hamann 2009). Mining, dredging, some agriculture and certain kinds of forestry operations are extractive processes that can undermine land surface stability; highways and railroads and urbanization are additive processes that modify the terrestrial surface; accelerated soil erosion, nuclear waste and sanitary landfill translocates sediment, solutes and nutrients; and grazing and accelerated chemical and biological changes associated with forestry and agriculture transform the terrestrial surface (Koch 1995, Lambin and Geist 2006). The lack of attention paid to land use as a factor in increasing geohazard vulnerability by comparison with the huge investment into climate change research has been deplored by Slaymaker (2001) for reasons discussed in the following sections.

\subsubsection{Forestry}

Forestry can be both an extractive and transformative resource use process (Slaymaker 2000). Timber harvesting in BC influences (a) forest hydrology, (b) fluvial geomorphology, (c) terrain stability and (d) integrated watershed behavior. Forest damage due to landslides on the Queen Charlotte Islands (Haida Gwaii) off the $\mathrm{BC}$ coast has reduced forest productivity of landslide areas by about $70 \%$ when compared with similarly aged logged areas (Smith et al 1986). Although forest cover is renewable after responsible harvesting, Vancouver Island, Haida Gwaii and the southern coast of British Columbia provide numerous examples of unsustainable forest management practices. Brardinoni et al (2002) considered the impacts of logging activities on mass movement in five watersheds in the Coast Mountains and found a recovery time of approximately 20 years after logging. The effects of logging on slope stability include increased debris flow and debris avalanche incidence affecting Pacific salmon spawning grounds, removed productive land from forestry use and contaminated water supplies. This became a major public issue in $\mathrm{BC}$ and was instrumental in the development of BC's Forest Practices Code (BC Ministry of Forests 1994). Haeberli and Burn (2002) have directed attention to the complex relations between permafrost thawing and forested lands in the northern Cordillera.

\subsubsection{Mining}

Mining is an extractive process and is widely distributed throughout the Cordillera. The environmental impact of mining includes erosion and contamination of soil, groundwater and surface water by chemicals from mining processes. In some cases, additional forest logging is done in the vicinity of mines to increase the available room for the storage of the created debris and soil. Erosion of exposed hillsides, mine dumps, tailings dams and resultant siltation of drainages, creeks and rivers can significantly impact the surrounding areas, a prime example being the Mount Polley tailings storage facility breach in the Interior Cordillera of BC that occurred in 2014. In areas of wilderness, mining may cause destruction and disturbance of ecosystems and habitats. Mining modifies stresses in a slope; Canada's largest landslide disaster, the 1903 Frank Slide, resulted from displacements induced by coal mining at the foot of the mountain. Some 75 fatalities ensued (Evans 2001). In southern British Columbia, destructive debris flows struck the mining town of Port Alice in 1973 and 1975 (Fig. 5). As a 
result, the first debris flow defensive structures built in Canada were constructed at that site.

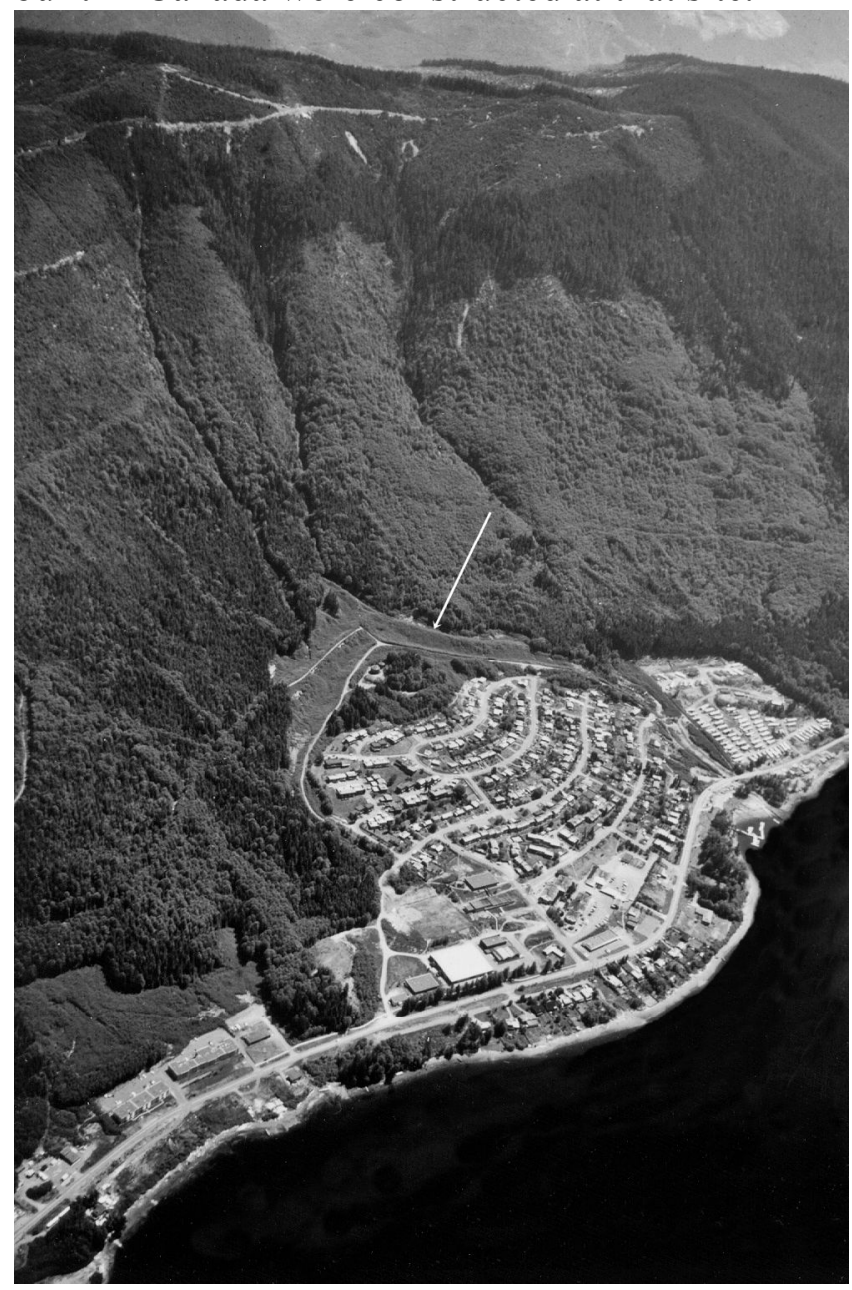

Figure 5. Mining town of Port Alice, Vancouver Island, British Columbia, showing debris deflection dykes constructed in 1976 to protect town from debris flows/floods. Reproduced with permission of Natural Resources Canada, 2015 (photos NRCAN 2000-082 by S.G. Evans)

\subsubsection{Agriculture}

Agriculture involves translocational, transformational and extractive processes and is focused in the Interior and Western cordilleras. In the Interior Plateau of the Canadian Cordillera, agriculture is only viable with the aid of irrigation. Destructive failures, particularly in the glacilacustrine silts of the semi-arid Okanagan valley, have resulted from over-irrigation.

\subsubsection{Urbanization}

Urbanization involves additive resource use processes. Because of the increasing population densities in western Canada's major cities, natural hazard susceptibility has increased proportionately. Whether the hazard be liquefaction potential and landslides as in Vancouver (Evans 1982), river flooding as in Calgary or Winnipeg, or natural landslides that occur along river banks as in Edmonton (Rutter et al 1998), natural hazard susceptibility and the associated risks are increasing.

The general problems of landslides and surficial deposits in urban areas of British Columbia have been discussed (Evans 1982). He noted that under urban development three groups of surficial materials are prone to slope failure. These are glacimarine and glacilacustrine sediments and diamictons. Glacimarine clays and glacilacustrine silts are sensitive and collapsible under certain moisture and loading conditions. Debris flows and debris floods (Porter et al 2007, Lyle 2013, Jakob et al 2013) in till mantles are a major geohazard in North Vancouver.

Urbanization modifies surface runoff, reduces water losses through evapotranspiration and may add significant amounts of water to natural groundwater systems through lawn and garden irrigation. In Calgary, this has led to higher ground water levels and reactivation of preexisting slope failures.

\section{Conclusion}

The landscape of the Canadian Cordillera is prone to naturally occurring geohazards that affect society. Of the three sudden-onset geohazards discussed above, river flooding is the costliest at regional scale and over century time scales but debris/rock avalanches are the deadliest at individual slope scale and over seasonal time scale. In terms of work done on the landscape, debris flows/floods are the most pervasive geohazard and have a huge influence on the longterm moulding of the landscape but figure less prominently in terms of fatalities and cost. Over the past several decades there has been a marked increase in both the frequency and cost of geohazards. The primary reasons for the increased cost are the increased concentration of population in geohazard prone areas, increased dependence of society on technology that is vulnerable to geohazards, and increased 
economic prosperity creating more wealth that is vulnerable to damage. Global climate change is an additional factor that may well affect the magnitude and frequency of many geohazards.

\section{References}

Ashmore, P. and M. Church, 2001. The impact of climate change on rivers and river processes in canada. Geological Survey of Canada Bulletin 555. Geological Survey of Canada, Ottawa.

Beltaos, S. and B.C. Burrell, 2003. Climatic change and river ice break up. Canadian Journal of Civil Engineering, 30: 145 - 155.

Brardinoni, F. and M. Church, 2004. Representing the landslide magnitudefrequency relation: Capilano River basin, BC. Earth Surface Processes and Landforms, 29: $115-124$.

Brardinoni, F., M. Hassan and O. Slaymaker, 2002. Complex mass wasting response of drainage basins to forest management in coastal BC. Geomorphology, 49: 109 - 124.

British Columbia Ministry of Forests, 1994. British Columbia Forest Practices Code: Standards with Revised Rules and Field Guide References. Victoria.

Brooks, G.R., S.G. Evans and J.J. Clague, 2001. Floods. In: Brooks, G.R. (ed.), A Synthesis of Geological Hazards in Canada. Geological Survey of Canada Bulletin 548, Ottawa: 101 144.

Church, M. and J.M. Ryder, 1972. Paraglacial sedimentation: a consideration of fluvial processes conditioned by glaciation. Geol. Soc. Amer. Bull, 83: 3059 - 3072.

Church, M. and O. Slaymaker, 1989. Disequilibrium of sediment yield in glaciated British Columbia. Nature, 337: 452 - 454

Clague, J.J. and S.G. Evans, 1994. Formation and failure of natural dams in the Canadian Cordillera. Geological Survey of Canada Bulletin 464.

Clague, J.J. and S.G. Evans, 1998. Natural hazards in the Canadian Cordillera. In: Moore, D.P. and O.Hungr (eds.), Engineering Geology: A Global View from the Pacific Rim. Proceedings of the $8^{\text {th }}$. International Congress,
International Association for Engineering Geology and the Environment. Vancouver.

Clarke, G.K.C., A.H. Jarosch, F.S. Anslow, V. Radic and B. Menounos, 2015. Projected deglaciation of western Canada in the twentyfirst century. Nature Geoscience, 8: 372 - 377. DOI: 10.1038/NGEO 2407.

Dyke, L.D. and G.R. Brooks, 2000. The physical environment of the Mackenzie Valley, NWT: A baseline for the assessment of environmental change. Geological Survey of Canada Bulletin 547.

Etkin, D., E. Haque, L. Bellisario and I. Burton, 2004. An Assessment of Natural Hazards and Disasters in Canada: A Report for Decision Makers and Practitioners. Environment Canada, Ottawa.

Evans, S.G., 1982. Landslides and surficial deposits in urban areas of $\mathrm{BC}$ : a review. Canadian Geotechnical Journal, 19: 269 - 288.

Evans, S.G., 1997. Fatal landslides and landslide risk in Canada. In: Cruden, D.M. and R. Fell (eds.), Landslide Risk Asessment: 185 - 196.

Evans, S.G., 2001. Landslides. In Brooks, G.R. (ed.), A Synthesis of Geological Hazards in Canada: Geological Survey of Canada Bulletin 548: 43 - 79.

Evans, S.G. and G.R. Brooks, 1991. Prehistoric debris avalanches from Mt. Cayley. Canadian Journal of Earth Sciences, 28: 1365 - 1374.

Evans, S.G. and J.J. Clague, 1997. The impact of climate change on catastrophic geomorphic processes in the mountains of Alberta, BC and the Yukon. In: Taylor, E. and W. Taylor (eds.), Responding to Global Climate Change in BC and the Yukon. Environment Canada, Vancouver: 7-1 to 7-16

Friele, P.A. and J.J. Clague, 2004. Large Holocene landslides from Pylon Peak, southwestern British Columbia. Canadian Journal of Earth Sciences, 41: 165 - 182.

Friele, PA. and J.J. Clague, 2009. Paraglacial geomorphology of Quaternary volcanic landscapes in the southern Coast Mountains, BC Geological Society of London, Spec. Pub. 320: 219 - 233.

Friele, P.A., M. Jakob and J.J. Clague, 2008. Hazard and risk from large landslides at Mt. Meager volcano. Georisk, 2: 48 - 64. 
Geertsema, M. and M. Chiarle, 2013. Mass movement causes: glacier thinning. In: Shroder, J.F., R.A. Marston and M. Stoffel (eds.), Treatise on Geomorphology vol 7, Mountain and Hillslope Geomorphology: 217 - 222. Academic Press, San Diego.

Geertsema, M., J.J. Clague, J.W. Schwab and S.G. Friele, 2006. An overview of recent large catastrophic landslides in northern BC. Engineering Geology, 83: 120 - 143.

Guthrie, R.H., P. Friele, K. Allstadt, N. Roberts, S.G. Evans, K.B. Delaney, D. Roche, J.J. Clague and M. Jakob, 2012. The 6 August, 2010 Mount Meager rock slide-debris flow, Coast Mountains, BC. Natural Hazards and Earth System Sciences, 12: 1 - 18.

Haeberli, W. and C.R. Burn, 2002. Natural hazards in forests: glacier and permafrost effects as related to climate change. In: Sidle, R.C. (ed.), Environmental Change and Geomorphic Effects in Forests. CABI, Wallingford: 167 - 202.

Hewitt, K., 1989. Glaciers of the Karakoram Himalayas: Glacial Environments, Processes, Hazards and Resources. Springer, Dordrecht.

Hewitt, K., 2006. Disturbance regime landscapes: mountain drainage systems interrupted by large landslides. Progress in Physical Geography, 30: 365 - 393.

Hungr, O., S.G. Evans, M.J. Bovis and J.N. Hutchinson, 2001. Environmental and Engineering Geoscience, vol 7: 221 - 238. Geological Society of America, Boulder, CO.

Jackson, L.E., 1987. Debris flow hazard in the Canadian Rocky Mountains. Geological Survey of Canada Paper 86-11, Geological Survey of Canada, Ottawa.

Jakob, M., K. Holm, H. Weatherley, S. Liu and N. Ripley, 2013. Debris flood risk assessment for Mosquito Creek, BC, Canada. Natural Hazards, 65: 1653 - 1681.

Johnson, P.G., 1984. Paraglacial conditions of instability and mass movement: a discussion. Zeitschrift fur Geomorphologie, 28: 235 - 250.

Jordan, P. and O. Slaymaker, 1991. Holocene sediment production in Lillooet River basin: a sediment budget approach. Geographie physique et Quaternaire, 45: 45 - 57.

Koch, N.K. 1995. Geohazards: Natural and
Human. Prentice-Hall, Englewood Cliffs, NJ .

Lambin, E.F. and H.J. Geist (eds.), 2006. Land Use and Land Cover Change: Local Processes and Global Impacts. Springer, Dordrecht.

Leopold, L.B. and T. Maddock, 1953. The hydraulic geometry of stream channels and some physiographic implications. US Geological Survey Professional Paper 252, Washington, DC

Locher, P. and F. Berna., 2014. Holocene human interaction and adaptation to geological and climatic changes in the Lower Mainland, Fraser Canyon and Coast Mountains area of BC: a geoarcheological view. In: Dashtgard, S. and B. Ward (eds.), Trials and Tribulations of Life on an Active Subduction Zone. GSA Field Guide 38, Boulder, CO: 53 - 78.

Lyle, T., 2013. Flood Hazard Study, North Vancouver. Geological Survey of Canada Open File 6697.

McBean, G.A., 2012. Telling the Weather Story. Institute for Catastrophic Loss Reduction (ICLR) for the Insurance Bureau of Canada. London, Ontario.

McBean, G.A., O.Slaymaker, T. Northcote, P. LeBlond and T.S. Parsons, 1991. Review of models for climate change and impacts on hydrology, coastal currents and fisheries in BC. Canadian Climate Centre Report 91-11, National Hydrology Research Centre, Saskatoon, SK.

Moore, R.D., S.W. Fleming, B. Menounos, R. Wheate, A. Fountain, K. Stahl, K. Holm and M. Jakob, 2009. Glacier change in western North America: influences on hydrology, geomorphic hazards and water quality. Hydrological Processes, 23: 42 - 61.

Orwin, J.F., J.J. Clague and R.F. Gerath, 2004. The Cheam rock avalanche, Fraser Valley, British Columbia. Landslides, 1: 289 - 298.

Porter, M., M. Jakob, K.W. Savigny, S. Fougere and N. Morgenstern, 2007. Risk management for urban flowslides in North Vancouver, Canada. Proceedings of the $60^{\text {th }}$. Canadian Geotechnical Conference, Ottawa.

Prowse, T.D. and S. Beltaos, 2002. Climatic control of river ice hydrology: a review. Hydrological Processes, 16: 805 - 822. 
Rutter, N.W., L.D. Andriashek, R. Stein and M.M. Fenton, 1998. Engineering geology of the Edmonton area. In: Karrow, P.F. and O.L. White (eds), Urban Geology of Canadian Cities. Geological Association of Canada, Special Paper 42: 71 - 92.

Ryder, J.M., 1998. Geomorphological Processes in the Alpine Areas of Canada: the effects of climate change and their impacts on human activities. Geological Survey of Canada Bulletin 524. Geological Survey of Canada, Ottawa.

Sandink, D., P. Kovacs, G. Oulahen and G. McGillivray, 2010. Making Flood Insurable for Canadian Homeowners. A Discussion Paper. Institute for Catastrophic Loss Reduction \& Swiss Reinsurance Company Ltd. Toronto, Ontario.

Shephard, M.W., E. Mekis, R.J. Morris, Y. Feng, X. Zhang, K. Kilcup and R. Felltwood, 2014. Trends in Canadian short-duration extreme rainfall: including an intensity-durationfrequency perspective. Atmosphere-Ocean, 52: $398-417$.

Slaymaker, O., 1988. The distinctive attributes of debris torrents. Hydrological Sciences Journal, 33: 567 - 572.

Slaymaker, O., 1999. Natural hazards in British Columbia: an interdisciplinary and interinstitutional challenge. International Journal of Earth Sciences, 88: 317 - 324.

Slaymaker, O., 2000. Assessment of the geomorphic impacts on forestry in BC. Ambio, 29: 381 - 387.

Slaymaker, O., 2001. Why so much concern about climate change and so little attention to land use change? The Canadian Geographer, 45: 71 - 78 .
Slaymaker, O. and C. Embleton-Hamann, 2009. Mountains. In: Slaymaker, O., T. Spencer and C. Embleton-Hamann (eds.), Geomorphology and Global Environmental Change. Cambridge University Press, Cambridge: 37 - 70.

Smith, R.B., P.R. Commandeur and M.W. Ryan, 1986. Soils, vegetation and forest growth on landslides and surrounding logged and old growth areas on the Queen Charlotte Islands. BC Ministry of Forests, Land Management Report 41.

Stryd, A.H. and M.K. Rousseau, 1996. The early prehistory of the Fraser-Thompson drainage area of British Columbia. In: Carlson, R.L. and L. Dalla Bona (eds.), Early Human Occupation in British Columbia. UBC Press, Vancouver: $185-190$.

Sutherland-Brown, A., 1969. Aiyansh lava flow, British Columbia. Canadian Journal of Earth Sciences, 6: 1460 - 1468.

Van Dine, D.F., 1985. Debris flows and debris torrents in the southern Canadian Cordillera. Canadian Geotechnical Journal, 22: 44 - 68.

Vitousek, P.M., H.A. Mooney, J. Lubchenco and J.M. Melillo, 1997. Human domination of earth's ecosystems. Science, 277: 494 - 499. DOI: $10.1126 /$ science.277.5325.494.

White, G., 1974. Natural Hazards. Oxford University Press, Oxford.

Woo, M.K., 1996. Hydrology of northern North America under global warming. In: Jones, J.A.A., C.M. Liu and M.K. Woo (eds.), Regional Hydrological Responses to Climate Change. Kluwer, Dordrecht: 73 - 86.

Zhang, X., K.D. Harvey, W.D. Hogg and T.R. Yuzyk, 2001. Trends in Canadian stream flow. Water Resources Research, 37: 987 - 998. 